\title{
Association of HLA Class I and Class II genes with bcr-abl transcripts in leukemia patients with $\mathbf{t}(9 ; 22)$ (q34; $\mathrm{II}$ ) Shailendra Mundhada, Rajyalakshmi Luthra and Pedro Cano*
}

\author{
Address: Department of Laboratory Medicine, Box 149, The University of Texas M. D. Anderson Cancer Center, Houston, TX 77030 \\ Email: Shailendra Mundhada - sgmundha@mdanderson.org; Rajyalakshmi Luthra - rluthra@mdanderson.org; \\ Pedro Cano* - pcano@mdanderson.org \\ * Corresponding author
}

Published: 17 June 2004

BMC Cancer 2004, 4:25

This article is available from: http://www.biomedcentral.com/I47/-2407/4/25 media for any purpose, provided this notice is preserved along with the article's original URL.

Received: 14 June 2003

Accepted: 17 June 2004

\begin{abstract}
Background: Based on the site of breakpoint in $\mathrm{t}(9 ; 22)(\mathrm{q} 34 ; \mathrm{q} \mathrm{I} \mathrm{I})$, bcr-abl fusion in leukemia patients is associated with different types of transcript proteins. In this study we have seen the association of HLA genes with different types of $b c r-a b l$ transcripts. The association could predict the bcr-abl peptide presentation by particular HLA molecules.

Methods: The study included a total of 189 patients of mixed ethnicity with chronic myelogenous leukemia and acute lymphocytic leukemia who were being considered for bone marrow transplantation. Typing of $b c r-a b l$ transcripts was done by reverse transcriptase PCR method. HLA typing was performed by molecular methods. The bcr-abl and HLA association was studied by calculating the relative risks and chi-square test.

Results: Significant negative associations $(p<0.05)$ were observed with HLA-A*02 (b2a2, ela2), $A^{*} 68$ (b2a2, b3a2, ela2), -B*14 (b2a2, b3a2, ela2), -B*15 (b2a2, b3a2), -B*40 (b2a2), -DQBI*0303 (b2a2, b3a2), -DQBI*0603 (b2a2), -DRBI*040I (ela2), -DRBI*070I (b3a2), and -DRBI*II0I (b2a2).

Conclusions: The negative associations of a particular bcr-abl transcript with specific HLA alleles suggests that these alleles play a critical role in presenting peptides derived from the chimeric proteins and eliciting a successful T-cell cytotoxic response. Knowledge of differential associations between HLA phenotypes and bcr-abl fusion transcript types would help in developing better strategies for immunization with the $b c r-a b l$ peptides against $t(9 ; 22)(q 34 ; q \mathrm{I})$-positive leukemia.
\end{abstract}

\section{Background}

The $\mathrm{t}(9 ; 22)$ ( $\mathrm{q} 34 ; \mathrm{q} 11)$ translocation seen in $90 \%$ of patients with chronic myelogenous leukemia (CML) and about $10 \%$ patients with acute lymphocytic leukemia (ALL) results in juxtaposition of the 3 ' segment of the $c$-abl proto-oncogene on chromosome 9 with the 5 ' segment on the $b c r$ gene on chromosome 22 [1-6]. Breaks in c-abl gene generally involve exon 2, also known as a2. Breaks in the $b c r$ occur in one of the three following regions: the major breakpoint cluster region ( $\mathrm{M}-b c r)$, the minor breakpoint cluster region $(\mathrm{m}-b c r)$ or the micro breakpoint cluster region $(\mu-b c r)$ [7]. Breakpoints occurring in $\mathrm{m}$-bcr involve introns 13 and 14 and join exon 13 or 14 with $a b l$, resulting in the fusion transcripts e13a2 (also known as b2a2) and e14a2 (also known as b3a2), respectively. These transcripts lead to production of a $8.5-\mathrm{kb}$ transcript coding for a $210-\mathrm{kD}$ chimeric protein (p210) [8,9]. Breakpoints in $\mathrm{m}-b c r$ involve the first intron of $b c r$, exon 1 joins with $a b l$, 
resulting in a smaller fusion transcript, e1a2, that codes for a 190-kD protein (p190) [10]. Breakpoints in the $\mu-b c r$ involve intron 19, the joining of exon 19 with abl results in a fusion transcript e19a2, that codes for a $230-\mathrm{kD}$ protein (p230) [11]. Although tyrosine kinase is activated in all bcr-abl fusion transcripts, the p190 form has been shown to have more transforming potential than p210 in vitro and in vivo [12-14]. Fusion transcripts b3a2 and b2a2, which are translated into p210, account for the majority of CML cases, while the fusion transcript e1a2, which is translated into $\mathrm{p} 190$, is seen primarily in $\mathrm{t}(9 ; 22)$ positive ALL and the blastic phase of CML $[10,15]$. The rare fusion transcript e19a2, resulting in p230, is associated primarily with the entity known as chronic neutrophilic leukemia [16].

Several reports indicate an association between $t(9 ; 22)$ (q34;q11) and different human leukocyte antigen (HLA) alleles. This association suggests a possible role for T-cell cytotoxicity in the pathogenesis of diseases linked to $b c r$ $a b l$ fusion proteins resulting from $\mathrm{t}(9 ; 22)(\mathrm{q} 34 ; \mathrm{q} 11)$. Different HLA alleles have different predilections for the sequence of peptides they can present to T cells. In order to elicit a T-cell response, a peptide must bind to the HLA molecule prior to its presentation to the T cell. Since a given HLA allele can bind and present only peptides with certain sequence constraints, the ability of an individual to elicit a successful T-cell cytotoxic response to cells carrying foreign or newly mutated proteins depends on the set of HLA alleles that individual has inherited. Thus, individuals carrying certain HLA alleles capable of binding peptides derived from $b c r-a b l$ fusion transcripts can in principle be considered to have a biological advantage in fighting the disease over individuals lacking these particular HLA alleles.

In studying the association between the distribution of HLA alleles in patients with different types of $b c r-a b l$ transcripts, a positive association suggests that a particular HLA allele does not effectively bind and present peptides derived from a given $b c r-a b l$ transcript. Likewise, a negative association suggests that the binding and presentation of a peptide is effective and elicits a successful T-cell cytotoxic response with destruction of leukemia cells.

The aim of this study was to analyze the disease association between HLA alleles and $b c r$-abl fusion transcripts in greater detail than has so far been studied. First, we assessed the HLA association with a particular $b c r-a b l$ transcript, i.e., b2a 2 or b3a2 or e1a2, and not with CML in general. Second, unlike earlier studies that were limited to low-resolution allele typing, this study used high-resolution typing for HLA class II genes.

\section{Methods}

A total of 189 patients comprising of 163 with CML and 26 with ALL, all with $\mathrm{t}(9 ; 22)(\mathrm{q} 34 ; \mathrm{q} 11)$ and known HLA types, were included in this study. Of these patients, 28 expressed b2a2 and b3a2 transcripts, while 68 expressed the $\mathrm{b} 2 \mathrm{a} 2$ transcript, 76 the $\mathrm{b} 3 \mathrm{a} 2$ transcript, and 17 the e1a2 transcript. The comparisons were made with healthy, potential bone marrow donors that were HLA typed at our laboratory. 376 donors were typed for HLA class I and 267 donors for HLA class II. The donor population is a multiracial group of both related and unrelated prospective bone-marrow donors with no significant clinical history. The gene frequencies are not at odds with reported gene frequencies in general populations for prevailing races. We decided to use our internal gene frequencies from this donor population for three reason: First, it is a multiracial group in which no racial bias was made, more representative of the population the reported patients came from than any specific racial group typically used to determine HLA gene frequencies. Second, it is a group for which high-resolution high-quality typing is readily available making it possible to evaluate allelic gene frequency differences, rather than differences at the serologic low-resolution level. Third, it is a group for which not only the HLA phenotype is available, but also the genotype, that is, the haplotypes were determined in each case, particularly in regard to class II genes.

\section{Typing of bcr-abl fusion transcripts by reverse- transcriptase PCR}

Leukocytes prepared by erythrocyte lysis of bone marrow aspirate $(1-2 \mathrm{ml})$ and peripheral blood $(10 \mathrm{ml})$ samples collected in ethylene diamine tetraacetic acid were used for RNA isolation. Total RNA was isolated by using Trizol reagent (Invitrogen Lifetechnologies, USA) according to the manufacturer's instruction. The integrity of RNA was determined by gel electrophoresis prior to reverse transcription (RT). Total RNA (1-5 $\mu \mathrm{g})$ from samples with intact $28 \mathrm{~s}$ and $18 \mathrm{~s}$ RNA was converted to cDNA by using random hexamers and Superscript II reverse transcriptase (Invitrogen Lifetechnologies) according to the recommendations of the manufacturer.

Each sample was amplified in duplicate for $b c r-a b l$ in a multiplex RT-PCR using an $a b l$ primer in combination with $b c r$ b2- and e1-specific primers [17]. The t(9;22)-positive cell lines KBM7, K562, and B15, which carry b2a2, b3a2, and e1a2 fusion genes, respectively, served as positive controls. $[18,19]$ The HL60 cell line was used as negative control.

\section{HLA typing}

HLA typing was performed by molecular methods. For class I, HLA typing was done at the intermediate-resolution level by using enzyme linked probe hybridization 
assay with sequence-specific oligonucleotide probe (ELPHA-SSOP) (Biotest, Germany). The sequence-specific oligonucleotide probes were used to identify polymorphic sequence motifs. The hybridization between probe and target DNA from the series of amplified PCR products was detected by a method adapted from the protein enzyme linked immunosorbent assay (ELISA) technique. For class II, HLA typing was done at the high-resolution level by using the sequence specific primers (SSP) (Genovision, USA or Pel-freez, USA). The technique uses a battery of known sequence specific primers to amplify specific alleles or group of alleles. This typing method is based on the fact that a completely matched primer will be used more efficiently in the PCR reaction than a partially mismatched primer. The electrophoresis bands generated were compared with the kit standards.

\section{Statistical analysis}

HLA gene frequencies (not phenotype frequency) were calculated in two different populations: (1) Healthy individuals typed as potential candidates for donating bone marrow; and (2) Patients diagnosed as having CML or ALL in whom $b c r-a b l$ transcripts were identified.

The sizes of the gene pools of these populations for HLA typing are shown in Table 1. In order to obtain more accurate gene frequencies, the largest population of typed donors was used. This resulted in a larger population for class I genes (376 individuals) than for class II genes (268 individuals). The frequencies of the HLA-A, -B, -DRB1 and -DQB1 alleles for the three groups of CML patients with different $b c r-a b l$ transcripts were compared with their gene frequencies in the healthy donor group. The frequencies of HLA alleles in patients were evaluated in 192 chromosomes of patients with b2a 2 transcirpts (96 individuals, 68 with only b2a 2 and 28 with both b2a2 and b3a2); 208 chromosomes of patients with b3a2 (104 individuals, 76 with only b3a 2 and 28 with both b2a 2 and b3a2); and 34 chromosomes of patients with e1a2 (17 individuals). The comparisons were made by calculating the relative risks. Chi-squares were also calculated to assess the statistical significance of the differences. With $(v)=(\mathrm{r}-1)(\mathrm{c}-1)=1$ degree of freedom and a significance level of $\alpha=0.05$ needed to reject the null hypothesis, the $\chi^{2}$ statistic must be $>3.84$. Since ours is an international referral center with a patient population of diverse racial backgrounds, it was not possible to compare the patient data with the standard HLA frequencies based on ethnicity. We therefore used the healthy bone marrow donor population for comparison.

The binding scores were calculated on the basis of the amino acid sequence of the peptide and the HLA molecule as described elsewhere [20-22]. The sequences of $\mathrm{e} 1 \mathrm{a} 2$, b3a2, and b2a2 junctional peptides are EGAFHG-
Table I:

\begin{tabular}{lllr}
\hline HEALTHY DONORS* & & CML + ALL* \\
\hline HLA Class I: & 752 & b2a2: & 192 \\
HLA Class II: & 538 & b3a2: & 208 \\
& & ela2: & 34 \\
\hline
\end{tabular}

*Numbers of HLA genes available in the different populations to calculate HLA allele frequencies (not the number of individuals in these populations taking into account that an individual carries two genes for each loci).

DAEALQRPVAS [10,15], ATGFKQSSKALQRPVAS [23], and IPLTINKEEALQRPVAS [24].

\section{Results and discussion}

Our findings are summarized in Tables 2,3,4, which include only statistically significant observations with $\chi^{2}>$ 3.84 , corresponding to a significance level of $p<0.05$. Relative risk $>1$ indicates that a particular HLA allele is more frequent in a patient population with a particular transcript than within the corresponding healthy population. Relative risk $<1$ indicates a negative association, with a gene frequency significantly smaller than in the corresponding general population. Significant negative associations with b2a2 were seen with HLA-A*02, $-A^{*} 68,-B * 14$, $-\mathrm{B}^{*} 15, \quad-\mathrm{B}^{*} 40, \quad-\mathrm{DQB} 1 * 0303, \quad-\mathrm{DQB} 1{ }^{*} 0603$, and DRB1*1101. Significant positive association was seen with HLA-A*01, -A*23, -A*66, -B*37, -B*38, -B*42, B*45, -B*49, -B*53，-B*56，-B*62，-DQB1*0201， DQB1*0402, -DQB1*0609, -DRB1*0301, -DRB1*0302, -DRB1*0901，-DRB1*1001，-DRB1*1201，-DRB1*1202, and -DRB1*1503 (Table 2).

Significant negative associations with $\mathrm{b} 3 \mathrm{a} 2$ were seen with HLA-A*68, - B $^{*} 14, \quad-\mathrm{B}^{*} 15, \quad-\mathrm{DQB} 1{ }^{*} 0303$, and DRB $1 * 0701$. Significant positive association were seen with HLA-A*25, -B*37, -B*49, -B*51, -B*53, -B*56, $\mathrm{B}^{*} 60,-\mathrm{B} * 62,-\mathrm{DQB} 1 * 0609$, -DRB1*0405, -DRB1*0802, DRB1*0901, -DRB1*1001, and -DRB1*1503 (Table 3).

Significant negative associations with e1a2 were seen with HLA-A*02, $-A^{*} 68,-B^{*} 14$, and -DRB ${ }^{*} 0401$. Significant positive association were seen with HLA-A*01, -A*11, $\mathrm{A}^{*} 26, \quad-\mathrm{B}^{*} 08, \quad-\mathrm{B}^{*} 49, \quad-\mathrm{B}^{*} 53, \quad-\mathrm{B}^{*} 62, \quad-\mathrm{DQB} 1 * 0201,-$ DQB1*0502, $\quad$-DRB1*0301， -DRB1*0802, and DRB $1 * 1601$ (Table 4$)$.

The relative maximum binding scores of various peptides with the HLA types are also shown in the corresponding tables. The scores are particularly high for HLA-A*02, $A^{*} 68,-B^{*} 14$, and $-B^{*} 53$ (all with b2a2), HLA-A*68, $\mathrm{B}^{*} 14$, and $-\mathrm{B}^{*} 62$ (all with b3a2) and HLA-A*01, $-\mathrm{A}^{*} 02$, $\mathrm{B}^{*} 08$, and $-\mathrm{B}^{*} 14$ (all with e1a2). 
Table 2: b2a2 association with HLA Class I and II in leukemia patients and healthy donors with statistical analysis

\begin{tabular}{|c|c|c|c|c|c|c|}
\hline HLA & ALLELE & LEUKEMIA PATIENTS* & HEALTHY DONORS* & RELATIVE RISK & CHI-SQUARE & BINDING SCORE \\
\hline$A$ & 01 & 32 & 78 & 1.76 & 6.35 & 3 \\
\hline A & 02 & 50 & 275 & 0.63 & 6.66 & 6 \\
\hline A & 23 & 9 & 13 & 2.85 & 6.12 & \\
\hline$A$ & 66 & 5 & 4 & 5.09 & 7.15 & \\
\hline$A$ & 68 & 5 & 107 & 0.16 & 19.20 & 6 \\
\hline B & 14 & 9 & 99 & 0.32 & 10.88 & 7 \\
\hline B & 15 & 6 & 60 & 0.37 & 5.56 & \\
\hline B & 37 & 3 & 2 & 5.94 & 4.87 & \\
\hline B & 38 & 7 & 11 & 2.55 & 3.89 & \\
\hline B & 40 & 3 & 64 & 0.17 & 11.22 & \\
\hline B & 42 & 3 & $\mathrm{I}$ & 11.90 & 7.40 & \\
\hline B & 45 & 5 & 5 & 3.99 & 5.48 & \\
\hline B & 49 & 3 & 2 & 5.94 & 4.87 & \\
\hline B & 53 & 9 & 3 & 12.26 & 22.38 & 9 \\
\hline B & 56 & 4 & 2 & 7.97 & 7.99 & \\
\hline B & 62 & 6 & 0 & 45060000.00 & 23.62 & 0 \\
\hline DQBI & 0201 & 23 & 36 & 1.89 & 5.29 & \\
\hline DQBI & 0303 & 4 & 30 & 0.36 & 3.90 & \\
\hline DQBI & 0402 & 10 & 9 & 3.22 & 6.95 & \\
\hline DQBI & 0603 & 8 & 50 & 0.42 & 5.11 & \\
\hline DQBI & 0609 & 4 & 0 & 21480000.00 & 11.25 & \\
\hline DRBI & 0301 & 23 & 36 & 1.89 & 5.29 & \\
\hline DRBI & 0302 & 3 & 0 & 16110000.00 & 8.43 & \\
\hline DRBI & 0901 & 4 & I & 11.40 & 7.47 & \\
\hline DRBI & 1001 & 5 & 2 & 7.15 & 7.41 & \\
\hline DRBI & 1101 & 10 & 53 & 0.50 & 3.89 & \\
\hline DRBI & 1201 & 3 & 0 & 16110000.00 & 8.43 & \\
\hline DRBI & 1202 & 2 & 0 & 10740000.00 & 5.61 & \\
\hline DRBI & 1503 & 5 & I & 14.33 & 10.13 & \\
\hline
\end{tabular}

*Figures shown are the gene frequencies. For a significance level of $=0.05$ needed to reject the null hypothesis, the chi square statistic must be $>$ 3.84

Interestingly, $1.6 \%$ of patients with $\mathrm{t}(9 ; 22)(\mathrm{q} 34 ; \mathrm{q} 11)$ lacked HLA-DRB3, -DRB4, and -DRB5 alleles. This contrasts with the healthy group of which only $0.13 \%$ lacked these alleles. The $2 \times 2$ contingency table analysis yielded a likelihood ratio of 25 and a $\chi^{2}$ of 42.8 , indicating a statistical significance of $p<0.001$.

The presence of $b c r-a b l$ transcripts in patients with leukemia appears to be associated with both HLA class I and II alleles. In general, exogenous antigens are processed to peptides in the endocytic compartment and are presented by HLA class II to CD4+ T cells. On the other hand, endogenous peptides resulting from cleavage of proteins are transferred by the transport-associated proteins to the endocytoplasmic reticulum. In the endocytoplasmic reticulum, these peptides bind to newly synthesized HLA class I molecules, and the resulting complexes are transported to the cell surface to be recognized by CD8+ T cells. It has been shown however, that endogenous antigens can be processed by both class I and class II HLA molecules [2527]. The bcr-abl transcripts in leukemia cells would be endogenous peptides and would normally be presented by HLA class I molecules. In our study and other studies cited in Table 5, negative associations with both HLA class I and II alleles have been seen. A possible explanation is that the $b c r-a b l$ transcripts are presented by both HLA class I and class II.

There are published reports of both negative and positive associations of $b c r-a b l$ transcripts with HLA class I and class II alleles (Table 5). By a positive association it is meant that individuals having a particular bcr-abl transcript are more likely to be endowed with a particular HLA phenotype. By a negative association it is meant that individuals showing a particular $b c r-a b l$ transcript are less likely to have a given HLA phenotype. Most of these studies were done with low-resolution HLA typing data. Posthuma et al claimed that HLA-A3 and -B8 are associated with a diminished risk of development of CML [28]. On the basis of a large multi-center data from the European bone marrow transplant program $(\mathrm{n}=1462)$, they also claimed that HLA-DR4 is associated with diminished risk 
Table 3: b3a2 association with HLA Class I and II in leukemia patients and healthy donors with statistical analysis

\begin{tabular}{|c|c|c|c|c|c|c|}
\hline HLA & ALLELE & LEUKEMIA PATIENTS* & HEALTHY DONORS* & RELATIVE RISK & CHI-SQUARE & BINDING SCORE \\
\hline$A$ & 25 & 4 & 4 & 3.74 & 3.94 & \\
\hline$A$ & 68 & 7 & 107 & 0.21 & 17.80 & 8 \\
\hline B & 14 & 5 & 99 & 0.16 & 19.57 & 5 \\
\hline B & 15 & 5 & 60 & 0.28 & 8.04 & \\
\hline B & 37 & 5 & 2 & 9.22 & 10.27 & \\
\hline B & 49 & 6 & 2 & 11.12 & 13.50 & \\
\hline B & 51 & 13 & 19 & 2.57 & 6.99 & 4 \\
\hline B & 53 & 5 & 3 & 6.14 & 7.91 & 3 \\
\hline B & 56 & 3 & 2 & 5.48 & 4.34 & \\
\hline B & 60 & 8 & 0 & 60080000.00 & 29.13 & \\
\hline B & 62 & 6 & 0 & 45060000.00 & 21.80 & 8 \\
\hline DQBI & 0303 & 4 & 30 & 0.33 & 4.62 & \\
\hline DQBI & 0609 & 3 & 0 & 16110000.00 & 7.78 & \\
\hline DRBI & 0405 & 4 & 2 & 5.25 & 4.51 & \\
\hline DRBI & 0701 & 21 & 99 & 0.50 & 7.72 & \\
\hline DRBI & 0802 & 3 & 1 & 7.84 & 4.43 & \\
\hline DRBI & 0901 & 4 & I & $10.5 \mid$ & 6.78 & \\
\hline DRBI & 1001 & 4 & 2 & 5.25 & 4.51 & \\
\hline DRBI & 1503 & 3 & 1 & 7.84 & 4.43 & \\
\hline
\end{tabular}

*Figures shown are the gene frequencies. For a significance level of $=0.05$ needed to reject the null hypothesis, the chi square statistic must be $>$ 3.84

of CML. They compared patient data with data from unaffected individuals from the registry of bone marrow donors worldwide $(\mathrm{n}=500596)$. The patients and controls were matched by country. The odds ratio for HLADR3 was 0.86 (95\% confidence interval CI $0.75-0.98$ ) and for -DR4 combined with -B8, was 0.84 (95\% CI 0.720.98 ) [29]. A limitation of this study was that no high-resolution class II typing was done. It was also assumed that all the CML patients expressed the p210 protein, which is present in a majority but not all cases of CML. Pawelec and Wagner have questioned their claim on the basis of its reliance on low-resolution typing and have stressed the need for high-resolution HLA typing [30]. Our present study not only used high-resolution HLA class II typing but also included all three types of $b c r-a b l$ transcripts (b2a2, b3a2, and e1a2). Significant negative associations with $p<0.05$ was seen with HLA-A*02 (b2a2, e1a2), $A^{*} 68$ (b2a2, b3a2, e1a2), -B*14 (b2a2, b3a2, e1a2), $\mathrm{B}^{*} 15$ (b2a2, b3a2), -B*40 (b2a2), -DQB1*0303 (b2a2, b3a2), -DQB1*0603 (b2a2), -DRB1*0401 (e1a2), DRB1*0701 (b3a2), and -DRB1*1101 (b2a2). In a similar study using high-resolution HLA-DRB1 typing, Yasukawa et al reported positive association with HLADRB1*1201 (b2a2), and -DRB1*0403, -DRB1*0802, $\mathrm{DRB}^{*} 1403, \mathrm{DRB} 1 * 1405$ (all with b3a2), and a negative association with -DRB1*0405, -DRB1*08032, DRB1*1502 (all with b2a2) and -DRB1*08032, and DRB1*1501 (both with b3a2) in a Japanese population (Table 5) [36]. However, the study included only 50 cases and included no patients with the e1a2 transcript. Fur- thermore, association with HLA-DQB1 typing was not assessed. Our study had a larger population $(n=189)$ though of mixed ethnicity. The common findings of the two studies include positive association with HLADRB1*1201 (b2a2) and -DRB1*0802 (b3a2). There were no common HLA alleles with a negative association.

Tabe 6 shows HLA class II haplotypes with increased frequency in patients with the various types of bcr-abl transcripts.

The patients in our study had HLA class II typing that included HLA-DRB1*, -DRB3*, -DRB4*, -DRB5*, $\mathrm{DQB1}{ }^{*}$ and -DPB1* . We included in our results the statistical data on HLA-DRB1* and -DQB1*. Our study is unique among published reports by incorporating HLADQB1 data. Unlike HLA-DRB1 and -DQB1, HLA-DRB3, DRB4, and -DRB5 are not expressed by all individuals; expression depends on the haplotype. An interesting observation was the fact that the frequencies of absence of HLA-DRB3, -DRB4 and -DRB5 phenotype were higher in the patient pool then in the healthy donors. This could imply that HLA-DRB3, -DRB4, and -DRB5 alleles are associated with $b c r-a b l$ transcript presentation.

The $b c r$-abl transcripts can generate a T-cell response [3134]. Successful allogeneic, autologous, and HLA-identical sibling dendritic cell immunization strategies against CML with b3a2-p210 peptide have also been tried, with generation of T-cell response [35-39]. There are reports of 
Table 4: ela2 association with HLA Class I and II in leukemia patients and healthy donors with statistical analysis

\begin{tabular}{|c|c|c|c|c|c|c|}
\hline HLA & ALLELE & LEUKEMIA PATIENTS* & HEALTHY DONORS* & RELATIVE RISK & CHI-SQUARE & BINDING SCORE \\
\hline$A$ & 01 & 9 & 78 & 3.18 & 8.91 & 5 \\
\hline$A$ & 02 & 6 & 275 & 0.38 & 4.76 & 8 \\
\hline A & 11 & 4 & 27 & 3.65 & 5.93 & 3 \\
\hline$A$ & 26 & 3 & 16 & 4.54 & 6.37 & \\
\hline$A$ & 68 & 0 & 107 & 0.00 & 5.48 & 3 \\
\hline B & 08 & 6 & 45 & 3.36 & 7.27 & 7 \\
\hline B & 14 & 0 & 99 & 0.00 & 5.13 & 7 \\
\hline B & 49 & 1 & 2 & 11.35 & 6.11 & \\
\hline B & 53 & 1 & 3 & 7.56 & 4.15 & 3 \\
\hline B & 62 & 3 & 0 & 22530000.00 & 66.52 & 2 \\
\hline DQBI & 0201 & 7 & 36 & 3.61 & 8.85 & \\
\hline DQBI & 0502 & 2 & 4 & 8.33 & 8.12 & \\
\hline DRBI & 0301 & 7 & 36 & 3.61 & 8.85 & \\
\hline DRBI & 0401 & 0 & 56 & 0.00 & 3.93 & \\
\hline DRBI & 0802 & 1 & 1 & 16.24 & 6.95 & \\
\hline DRBI & 1601 & 2 & 2 & 16.72 & 13.96 & \\
\hline
\end{tabular}

*Figures shown are the gene frequencies. For a significance level of $=0.05$ needed to reject the null hypothesis, the chi square statistic must be $>$ 3.84 .

Table 5: Published data on HLA association with bcr-abl transcripts

\begin{tabular}{|c|c|c|c|}
\hline & b2a2 & b3a2 & ela2 \\
\hline \multirow[t]{4}{*}{ POSITIVE ASSOCIATION } & DRBI*I20I [42] & DRBI*0423 [42] & \\
\hline & & $\mathrm{DRBI} * 0802[42]$ & \\
\hline & & DRBI*1423 [42] & \\
\hline & & DRBI*I425 [42] & \\
\hline \multirow[t]{3}{*}{ NEGATIVE ASSOCIATION } & $\mathrm{DRBI} * 0425[42]$ & DRBI*08032 [42] & \\
\hline & DRBI*08032 [42] & DRBI*I50I [42] & \\
\hline & DRBI*I502 [42] & & \\
\hline \multirow[t]{13}{*}{ PEPTIDE PRESENTATION } & A2.1 [43] & A2.I [43] & DR4 [29] \\
\hline & $\mathrm{A} 3[28,44,45]$ & $\mathrm{A} 3[28,44,45,47]$ & DRBI*I50I $[40,4 I]$ \\
\hline & AlI $[28,44]$ & AlI $[28,44,47]$ & \\
\hline & B8 $[28,44]$ & B8 $[28,44,47]$ & \\
\hline & DRI $[23,30,46]$ & DRI $[23,30,46]$ & \\
\hline & DR2 $[30,46]$ & DR2 $[30,46]$ & \\
\hline & DR3 $[30,46]$ & DR3 $[30,46]$ & \\
\hline & DR4 $[30,46]$ & DR4 $[30,46]$ & \\
\hline & & DRII [44] & \\
\hline & & DRBI*0IOI [23] & \\
\hline & & DRBI*030I [48] & \\
\hline & & $\mathrm{DRBI} * 0423[46]$ & \\
\hline & & DRBI*090I [42] & \\
\hline
\end{tabular}

successful in vitro generation of HLA-DRB1*1501restricted p190 minor bcr-abl (e1a2)-specific CD4+ T lymphocytes in ALL $[40,41]$. The restriction was confirmed by loss of the cytotoxic effect in the presence of anti-HLA-DR and preservation of the effect when anti-HLA class I was used.

\section{Conclusions}

It seems that $b c r$-abl peptides are presented by many different HLA types. The negative association could occur because the early leukemogenic events are contained by a T-cell cytotoxic response and this prevents disease proliferation. A positive association could mean that the HLA molecules do not present the bcr-abl transcripts. We hold 
Table 6: HLA class II haplotypes positively associated with bcr-abl transcripts. (Each line represents a haplotype. An "X" indicates positive association with the respective transcript.)

\begin{tabular}{|c|c|c|c|c|c|c|c|}
\hline DRB I & DRB3 & DRB4 & DRB45 & DQB I & b2a2 & b3a2 & ela2 \\
\hline 090102 & & 01030101 & & 030302 & $x$ & $x$ & \\
\hline 1503 & & & 010101 & 0602 & $x$ & $x$ & \\
\hline 1001 & & & & 050101 & $x$ & $x$ & \\
\hline 080201 & & & & 0402 & & $x$ & \\
\hline 040501 & & 01030101 & & 0302 & & $x$ & \\
\hline 160101 & & & 0202 & 050201 & & & $x$ \\
\hline 030101 & 이이이 & & & 0201 & & & $x$ \\
\hline
\end{tabular}

the theoretical assumption that HLA-restricted T-cell cytotoxicity performs an immunosurveillance role in the pathogenesis of bcr-abl-transcript leukemias. Should this assumption hold, knowledge of the HLA association with different $b c r-a b l$ transcripts would have diagnostic and prognostic implications. It would also help in improving strategies of immunization with the bcr-abl peptides against $\mathrm{t}(9 ; 22)$ (q34;q11) leukemia.

\section{Competing interests}

None declared.

\section{Authors' contributions}

SM carried out the data collection and analysis and writing the manuscript. The $b c r-a b l$ typing was done in the lab of RL. HLA typing was done in the lab supervised by PC. RL and PC did the study design and analysis of the data. All authors read and approved the final manuscript.

\section{Acknowledgements}

We wish to acknowledge the editorial assistance by Ms. Kathryn Hale, Department of Scientific Publications, M. D. Anderson Cancer Center.

\section{References}

I. Nowell PC, Hungerford DA: A minute chromosome in human chronic granulocytic leukemia. Science 1960, I32: I 197-I 200.

2. Catovsky D: Ph I-positive acute leukaemia and chronic granulocytic leukaemia: one or two diseases? Br J of Haematol 1979, 42:493-498.

3. Rowley JD: A new consistent chromosomal abnormality in chronic myelogenous leukemia identified by quinacrine fluorescence and Giemsa staining. Nature 1973, 243:290-293.

4. de Kleinn A, Van Kessel AG, Grosveld D, Bartram CR, Hagemeijer A, Bootsma D, Spurr NK, Heisterkamp N, Groffen J, Stephenson JR: A cellular oncogene is translocated to the Philadelphia chromosome in chronic myelocytic leukemia. Nature 1982 , 300:765-767.

5. Groffen J, Stephenson JR, Heisterkamp N, de Klein A, Bartram CR, Grosveld G: Philadelphia chromosomal breakpoints are clustered within a limited region, bcr, on chromosome 22 . Cell 1984, 36(I):93-99.

6. Kantarjian HM, Deisseroth A, Kuzrock R, Estrov Z, Talpaz M: Chronic myelogenous leukemia: A concise update. Blood 1993, 82:69|-703.

7. Melo JV: The diversity of BCR-ABL fusion proteins and their relationship to leukemia phenotype. Blood 1996, 88:2375-2384.
8. Shtivelman E, Lifshitz B, Gale RP, Canaani E: Fused transcript of abl and bcr genes in chronic myelogenous leukemia. Nature 1985 , 3 1 5:550-554.

9. Ben-Nariah Y, Daley GQ, Mes-Masson AM, Witte ON, Baltimore D: The chronic myelogenous leukemia-specific $\mathrm{p} 210$ protein is the product of the bcr-abl hybrid gene. Science 1986, 233:2|2-2|4.

10. Hermans A, Heisterkamp N, von Linden M, van Baal S, Meijer D, vander Plas D, Wiedermann LM, Groffen J, Bootsma D, Grosveld G: Unique fusion of bcr and c-abl genes in Philadelphia chromosome-positive acute lymphoblastic leukemia. Cell 1987, 5 I:33-40.

II. Saglio G, Guerrasio A, Rosso C, Zaccaria A, Tassinari A, Serra A, Rege Cambrin G, Mazza U, Gavosto F: New type of BCR/ABL junction in Philadelphia chromosome-positive chronic myelogenous leukemia. Blood 1990, 76:1819-1824.

12. McLaughlin J, Chianese E, Witte ON: Alternative forms of the bcr-abl oncogene have quantitatively different potencies for stimulation of immature lymphoid cells. Mol Cell Biol 1989, 9:1866-1874.

13. Lugo TG, Pendergast AM, Muller AJ, Witte ON: Tyrosine kinase activity and transformation potency of bcr-abl oncogene products. Science 1990, 247:1079-1082.

14. Heisterkamp N, Jenster G, Ten Hoeve J, Zovich D, Pattengale PK, Groffen J, Bootsma D, Grosveld G: Acute leukemia in BCR/ABL transgenic mice. Nature 1990, 344:25I-253.

I5. Fainstein E, Marcelle C, Rosner A, Canaani E, Gale RP, Dreazen O, Smith SD, Croce CM: A new fused transcript in Philadelphia chromosome-positive acute lymphocytic leukaemia. Nature 1987, 330:386-388.

16. Pane F, Frigeri F, Sindona M, Luciano L, Ferrara F, Cimino R, Meloni G, Saglio G, Salvatore F, Rotoli B: Neutrophilic-chronic myeloid leukemia: a distinct disease with a specific molecular marker (BCR/ABL with C3/A2 junction). Blood 1996, 88:24I0-24I4.

17. Cross NC, Feng L, Chase J, Bungey J, Hughes TP, Goldman JM: Competitive polymerase chain reaction to estimate the number of BCR-ABL transcripts in chronic myeloid leukemia patients after bone marrow transplantation. Blood 1993, 82:1929-1936.

18. Lozzio CB, Lozzio BB: Human chronic myelogenous lekemia cell-line with positive Philadelphia chromosome. Blood 1975, 45:32l-334

19. Andersson BS, Collins VP, Kurzrock R, Larkin DW, Childs C, Ost A, Cork A, Trujillo JM, Freireich EJ, Siciliano MJ, Deisseroth AB: KBM7, a human myeloid leukemia cell line with double Philadelphia chromosomes lacking normal C-ABL and BCR transcripts. Leukemia 1995, 9:2100-2108.

20. Cano P, Fan B, Stass S: A geometric study of the amino acid sequence of class I HLA molecules. Immunogenetics I998, 48:324-334

21. Cano P, Fan B: A geometric and algebraic view of MHC-peptide complexes and their binding properties. BMC Structural Biology 200I, I:2.

22. Cano P: The propositional calculus of peptide binding to the major histocompatibility complex. In: Immunobiology of the Human MHC: Proceedings of the 13th International Histocompatibility Workshop and Conference, Seattle, WA 2002 in press. 
23. Mannering SI, McKenzie JL, Fearnley DB, Hart DNJ: HLA-DR Irestricted bcr-abl (b3a2)-specific CD4+ $T$ lymphocytes respond to dendritic cells pulsed with $\mathrm{b} 3 \mathrm{a} 2$ peptide and antigen presenting cells exposed to b3a2-containing cell lysates. Blood 1997, 90:290-297.

24. Grosveld G, Verwoerd T, van Agthoven T, de Klein A, Ramchandran KL, Heisterkamp N, Stam K, Groffen J: The chronic myelocytic cell line $\mathrm{K} 562$ contains a breakpoint in bcr and produces a chimeric bcr/c-abl transcript. Mol Cell Biol I986, 6(2):607-616

25. Nuchtern JG, Biddison WE, Klausner RD: Class II MHC molecules can use the endogenous pathway of antigen presentation. Nature 1990, 343:74-76.

26. Weiss S, Bogen B: MHC class II restriction presentation of intracellular antigen. Cell 1991, 64:767-776.

27. Mainati MS, Marti M, LaVaute T: Processing pathways for presentation of cytosolic antigen to MHC class II-restricted T cells. Nature 1992, 357:702-704.

28. Posthuma EFM, Falkenburg JHF, Apperley JF, Roosnek E, Oudshoorn M, Schipper RF, Schreuder GMT, D'Amaro J, van Biezen JH, Hermans J. Willemze R, Niederwieser D: HLA-B8 and HLA-A3 coexpressed with HLA-B8 are associated with a reduced risk of the development of chronic myeloid leukemia. Blood 1999, 93:3863-3865

29. Posthuma EFM, Falkenburg JHF, Apperley JF, Hertenstein B, Schipper RF, Oudshoorn M, v Biezen JH, Hermans J, Willemze R, Roosnek E, Niederwieser D: HLA-DR4 is associated with a diminished risk of the development of chronic myeloid leukemia (CML). Leukemia 2000, 14:859-862.

30. Pawelec G, Wagner W: Is HLA-DR4 or the HLA-DRB I*0402 allele association with decreased risk for CML? Leukemia 200I, I5(5): 192-193.

3I. ten Bosch GJ, Joosten AM, Kessler JH, Melief CJ, Leeksma OC: Recognition of BCR-ABL positive leukemic blasts by human CD4+ T cells elicited by primary in vitro immunization with a BCR-ABL breakpoint peptide. Blood 1996, 88:3522-3527.

32. ten Bosch GJ, Toornvliet AC, Friede T, Melief CJM, Leeksma OC: Recognition of peptides corresponding to the joining region of p210 bcr-abl protein by human T cells. Leukemia 1995, 9:1344-1348

33. Yasukawa M, Ohminami H, Kojima K, Hato T, Hasegawa A, Takahashi $\mathrm{T}$, Hirai H, Fujita S: HLA class II-restricted antigen presentation of endogenous bcr-abl fusion protein by chronic myelogenous leukemia-derived dendritic cells to CD4+ lymphocytes. Blood 200I, 98: 1498-1505.

34. Yasukawa $M$, Ohminami $H$, Kaneko $S$, Yakushijin $Y$, Nishimura $Y$, Inokuchi K, Miyakuni T, Nakao S, Kishi K, Kubonishi I, Dan K, Fujita S: CD4+ cytotoxic T-cell clones specific for bcr-abl b3a2 fusion peptide augment colony formation by chronic myelogenous leukemia cells in a b3a2-specific and HLA-DRrestricted manner. Blood 1998, 92:3355-3361.

35. Osman Y, Takahashi M, Zheng Z, Koike T, Toba K, Liu A, Furukawa T, Aoki S, Aizawa Y: Generation of bcr-abl-specific cytotoxic Tlymphocytes by using dendritic cells pulsed with bcr-abl (b3a2) peptide: its applicability for donor leukocyte transfusions in marrow-grafted CML patients. Leukemia 1999 13:166-174.

36. Westermann J, Kopp J, Korner I, Richter G, Qin Z, Blankenstein T, Dorken B, Pezzutto A: Bcr/abl+ autologous dendritic cells for vaccination in chronic myeloid leukemia. Bone Marrow Transplant 2000, 25(Suppl 2):S46-49.

37. Cullis JO, Barett AJ, Goldman JM, Lechler RI: Binding of BCR/ABL junctional peptides to major histocompatibility complex (MHC) class I molecules: studies in antigen processing defective cell lines. Leukemia 1994, 8: 165-I70.

38. Pinilla-lbarz J, Cathcart K, Korontsvit T, Soignet S, Bocchia M, Caggiano J, Lai L, Jimenez J, Kolitz J, Scheinberg DA: Vaccination of patients with chronic myelogenous leukemia with bcr-abl oncogene breakpoint fusion peptides generates specific immune responses. Blood 2000, 95: 178I-1787.

39. Baxevanis CN, Voutsas IF, Tsitsilonis QE, Gritzapis AD, Sotiriadou R, Papamichail M: Tumor-specific CD4+ T lymphocytes from cancer patients are required for optimal induction of cytotoxic T cells against the autologous tumor. I Immunol 2000, 164:3902-3912

40. Tanaka Y, Takahashi T, Nieda M, Masuda S, Kashiwase K, Ogawa S, Chiba S, Juji T, Hirai H: Generation of HLA-DRBI*I50I- restricted pl90 minor bcr-abl (ela2)-specific CD4+ T lymphocytes. $\mathrm{Br} J$ of Haematol 2000, 109:435-437.

4I. Tanaka Y, Takahashi T, Nieda M, Masuda S, Kashiwase K, Takahashi T, Ogawa S, Chiba S, Juji T, Hirai H: Generation of FAS-independent CD4 + cytotoxic T cell clone specific for p 190 minor bcrabl fusion peptide. Leuk Res 2002, 26:317-32I.

42. Yasukawa M, Ohminami H, Kojima K, Inokuchi K, Nishimura Y, Fujita S: Analysis of HLA-DRBI alleles in Japanese patients with chronic myelogenous leukemia. Am J Hematol 2000, 63(2):99-101.

43. Yotunda P, Firat H, Garcia-Pons F, Garcia Z, Gourru G, Vernant J, Lemonnier FA, Leblond V, Langlade-Demoyen P: Cytotoxic T-cell response against the chimeric p210 BCR-ABL protein in patients with chronic myelogenous leukemia. J Clin Invest I998, I0I:2290-2296.

44. Bocchia M, Korontsvit T, Xu Q, Mackinnon S, Yang SY, Sette A, Scheinberg DA: Specific human cellular immunity to bcr-abl oncogene-derived peptides. Blood 1996, 87:3587-3592.

45. Greco G, Fruci D, Accapezzato D, Barnaba V, Nisini R, Alimena G, Montefusco E, Vigneti E, Butler R, Tanigaki N, Tosi R: Two bcr-abl junctional peptides bind HLA-A3 molecules and allow specific induction of human cytotoxic T lymphocytes. Leukemia 1996, 10:693-699.

46. ten Bosch GJ, Kessler JH, Joosten AM, Bres-Vloemans AA, Geluk A, Godthelp BC, van Bergen J, Melief C], Leeksma OC: A BCR-ABL oncoprotein p2 $10 \mathrm{~b} 2 \mathrm{a} 2$ fusion region sequence is recognized by HLA-DR2a-restricted cytotoxic $T$ lymphocytes and presented by HLA-DR-matched cells transfected with an L-li (b2a2) construct. Blood 1999, 94(3): 1038-1045.

47. Norbury LC, Clark RE, Christmas SE: b3a2 BCR-ABL fusion peptides as targets for cytotoxic $T$ cells in chronic myeloid leukemia. Brj of Haematol 2000, 109(3):616-62I.

48. Clark RE, Dodi IA, Hill SC, Lill JR, Aubert G, Macintyre AR, Rojas J, Bourdon A, Bonner PL, Wang L, Christmas SE, Travers PJ, Creaser CS, Rees RC, Madrigal JA: Direct evidence that leukemic cells present HLA-associated immunogenic peptides derived from the BCR-ABL b3a2 fusion protein. Blood 200I, 98(10):2887-2893

\section{Pre-publication history}

The pre-publication history for this paper can be accessed here:

\section{http://www.biomedcentral.com/1471-2407/4/25/prepub}

Publish with Bio Med Central and every scientist can read your work free of charge

"BioMed Central will be the most significant development for disseminating the results of biomedical research in our lifetime. "

Sir Paul Nurse, Cancer Research UK

Your research papers will be:

- available free of charge to the entire biomedical community

- peer reviewed and published immediately upon acceptance

- cited in PubMed and archived on PubMed Central

- yours - you keep the copyright

Submit your manuscript here:

http://www.biomedcentral.com/info/publishing_adv.asp
BioMedcentral 